\title{
Prenatal Diagnosis of Galactosaemia
}

\author{
A. H. FENSOM, P. F. BENSON, S. BLUNT
}

from the reaction mixtures the rate of reduction of $\mathrm{NAD}(\mathrm{P})$ in amniotic cells was only about $25 \%$ less than in the complete systems.

\section{Summary}

We have monitored two pregnancies from families at risk for galactosaemia. The fetus was diagnosed as having galactosaemia in one and to be unaffected in the other. The accuracy of the predictions was confirmed postnatally. Assays for galactose 1-phosphate uridyl transferase involving the reduction of the coenzymes NAD or NADP are unsuitable for amniotic cells whereas estimation of ${ }^{14} \mathrm{C}$-UDP-galactose produced from ${ }^{14} \mathrm{C}$ galactose 1-phosphate detected the homozygous mutant fetus.

\section{Introduction}

While the acute clinical features of galactosaemia can be reversed rapidly by removal of galactose from the diet the long-term prognosis of mental development is less encouraging even when galactosaemia is diagnosed early and treated well. Thus, the intelligence of 18 out of 23 affected children in a British series was found to be lower than normal, the mean I.Q. being depressed by 34 points (Komrower and Lee, 1970). This trend has also been reported in two American series though measured intelligence was rather higher. In one of these (Donnell et al., 1969) 29 out of 41 children (71\%) had I.Q.s of 85 or higher and in the other (Nadler et al., 1969) 26 out of 44 $(59 \%)$ had I.Q.s of 90 or higher. In view of unequivocal evidence that poor dietary control leads to mental subnormality it is reasonable that parents who have proved unable to maintain strict galactose deprivation should elect for prenatal diagnosis and termination of pregnancy if the fetus is affected. Since transferase deficiency has been reported in cultured amniotic cells collected by amniocentesis performed immediately before caesarian section at 33 weeks (Nadler, 1968) it seemed probable that galactosaemia could be detected in utero at a stage when the pregnancy could be terminated if the fetus was affected.

After birth the diagnosis of galactosaemia is confirmed by showing a severe deficiency of galactose 1-phosphate uridyl transferase (EC 2, 7, 7, 12 "transferase") in haemolysates. The enzyme is assayed usually by monitoring either the consumption of uridine diphosphoglucose (UDPG) (Anderson et al., 1957) or the production of glucose 1-phosphate (Beutler and Baluda, 1966; Nadler et al., 1970). In the former assay residual UDPG is measured using the NAD-linked UDPG dehydrogenase reaction. The production of glucose 1-phosphate is measured after conversion of the glucose 1-phosphate to glucose 6phosphate using the NADP-linked glucose 6-phosphate dehydrogenase and 6-phosphogluconate dehydrogenase reactions. The specificity of these assays, however, depends on the absence of other $\mathrm{NAD}(\mathrm{P})$-coupled dehydrogenases acting on components of the reaction mixture. We have confirmed that this condition is satisfied for erythrocytes but (as in the case of fibroblasts; Russell and DeMars, 1967) not for amniotic cells. Thus, when the substrate galactose 1-phosphate was excluded

Paediatric Research Unit, Guy's Hospital Medical School, London SE1 9RT

A. H. FENSOM, B.SC., PH.D., Biochemist

P. F. BENSON, M.D., M.R.C.P., Biochemical Geneticist S. BLUNT, B.SC., Research Assistant

\section{Methods and Patients}

\section{AMNIOTIC CELLS}

Clear amniotic fluid $(12 \mathrm{ml})$ was collected by suprapubic amniocentesis after localization of the placenta by ultrasound. Amniotic cells were collected from the fluid by centrifugation, resuspended in $2 \mathrm{ml}$ of HEPES buffered TC-199 medium supplemented with $20 \%$ human serum, other nutrients, and antibiotics. Growth was initially established in two Falcon petri dishes. Routine maintenance of the culture, including subculture, was carried out until enzyme assay.

\section{ENZYME ASSAY}

Transferase activity was measured by a modification of the method of Russell and DeMars (1967) which depends upon measurement of ${ }^{14} \mathrm{C}$-UDP-galactose produced from ${ }^{14} \mathrm{C}$ galactose 1-phosphate. Unreacted galactose 1-phosphate is then degraded by alkaline phosphatase treatment. The reaction product, ${ }^{14} \mathrm{C}$-UDP-galactose, was recovered on DEAE-cellulose paper since this was simpler than charcoal powder (Nadler, 1968; $\mathrm{Ng}$ et al., 1964) and because the latter method has been found to be unsatisfactory (Russell and DeMars, 1967; Fensom and Benson, 1974).

Amniotic cells were detached from the culture vessels using a solution of edetic acid $(0.02 \%)$ in Dulbecco A phosphatebuffered saline (Oxoid), washed twice with saline $(0.9 \%)$, and resuspended (about $5 \times 10^{6}$ cells $/ \mathrm{ml}$ ) in water containing triton $X-100(0.0025 \%)$. The cells were disrupted by sonication for one minute in an M.S.E. $150 \mathrm{~W}$ ultrasonic disintegrator. The reaction mixture contained the following components: $9.0 \mathrm{mM}{ }^{14} \mathrm{C}$-galactose 1-phosphate $(2.79 \mathrm{mCi} /$ $\mathrm{mmol}$ ), $250 \mu \mathrm{l} ; 7.3 \mathrm{mM}$ UDP-glucose, $125 \mu \mathrm{l} ; 0.5 \mathrm{M}$ glycine$\mathrm{NaOH}$ buffer (pH 8.7), $250 \mu \mathrm{l}$; and $12.5 \mathrm{mM}$ cysteine $\mathrm{HCl}$ adjusted to $\mathrm{pH} 8.7$ with $0.2 \mathrm{M} \mathrm{NaOH}$ just before use, $500 \mu$ l.

Then $50 \mu \mathrm{l}$ of this mixture and $20 \mu \mathrm{l}$ of the disrupted amniotic cell suspension were incubated at $37^{\circ} \mathrm{C}$. The reaction was stopped after incubation at intervals for up to 30 minutes by placing the tubes in a bath of boiling water for two minutes.

To each tube was added $25 \mu \mathrm{l}$ of a solution containing iodoacetamide (B.D.H. "biochemical grade") (25 mM) and sodium hydroxide $(10 \mathrm{mM})$ followed by $20 \mu 1$ of Escherichia coli alkaline phosphatase (Boehringer). The tubes were reincubated for two hours at $37^{\circ} \mathrm{C}$ to convert unreacted galactose 1-phosphate to galactose.

An aliquot from each tube was spotted on to a square $(2.5 \times$ $2.5 \mathrm{~cm}$ ) of Whatman DEAE-cellulose paper (type DE81) contained in a liquid scintillation phial. The papers were washed three times in the phials with $15 \mathrm{ml}$ of distilled water at $55^{\circ} \mathrm{C}$ and dried overnight at $40^{\circ} \mathrm{C}$, and the bound ${ }^{14} \mathrm{C}$ radioactivity was assayed in a liquid scintillation counter (Beckman model). Zero time blanks were 180-220 c.p.m. per sample. Protein was estimated by the method of Lowry et al. (1951).

Using this method we monitored two pregnancies in different families at risk for galactosaemia.

Case 1. - This 26-year-old woman had previously been delivered of a son with galactosaemia confirmed by blood transferase assays. In her subsequent pregnancy amniocentesis was performed at 13 weeks' gestation. Amniotic cells were cultured and assayed after 
three and five weeks. Transferase activity was $0.45 \%$ of the control mean of 38.9 units ( $\mu \mathrm{mol}$ of UDP galactose formed/hr) per gramme of protein (range $33.7 \mathrm{U}-54 \cdot 1 \mathrm{U} / \mathrm{g}$ protein), the fetus being judged to be affected. The parents decided to continue with the pregnancy, and the mother was delivered at term when the diagnosis of galactosaemia was confirmed by blood transferase assay.

Case 2.-This 25-year-old woman had previously been delivered of a girl with galactosaemia, who at 2 years 9 months had a blood transferase activity of 3.9 units per gramme of haemoglobin. Both the girl's parents had activities in the heterozygote range (mother $21.2 \mathrm{U} / \mathrm{g} \mathrm{Hb}$; father $17.7 \mathrm{U} / \mathrm{g} \mathrm{Hb}$; normal adult mean $34.0 \mathrm{U} / \mathrm{g} \mathrm{Hb}$; range $29.5 \mathrm{U}-38.5 \mathrm{U} / \mathrm{g} \mathrm{Hb}$ ). In the pregnanoy we studied amniocentesis was performed at 15 weeks' gestation. After three weeks of culture amniotic cells were found to have normal transferase activity $(43.3 \mathrm{U} / \mathrm{g}$ protein), the fetus being judged to be unaffected. We confirmed this at birth by showing normal cord blood transferase activity $(41 \cdot 6 \mathrm{U} / \mathrm{g} \mathrm{Hb})$.

\section{Conclusion}

These results suggest that assay of transferase activity on amniotic cells collected at amniocentesis and cultured for about three weeks allows accurate prenatal diagnosis of galactosaemia. Methods for assay which depend on reduction of the enzymes
NAD or NADP, however, are unsuitable for amniotic cell transferase assays.

We thank Dr. R. M. Todd and Dr. C. Nourse for allowing us to report the patients who were under their care (cases 1 and 2 respectively), and the Department of Health and Social Security and the Spastics Society for support.

\section{References}

Anderson, E. P., ot al. (1957). Fournal of Laboratory and Clinical Medicine, 50, 469.

Beutler, E., and Baluda, M. C. (1966). Fournal of Laboratory and Clinical Medicine, 67, 947 .

Donnell, G. N., Koch, R., and Bergren, W. R. (1969). Galactosaemia, ed. D. Y. Y. Hsia, p. 247. Springfield, Charles C. Thomas.

Fensom, A. H., and Benson, P. F. (1974). In preparation.

Komrower, G. M., and Lee, D. H. (1970). Archives of Diseases in Childhood, 45,367 .

Lowry, O. H., et al. (1951). Fournal of Biological Chemistry, 193, 265.

Nadler, H. L. Inouye, T, and Hsia, D Y Y Y (1969). Galactosaemia, ed. D. Y. Y. Hnouye, T., and Hsia, D. Y. Y. (1969). Galact

Nadler, H. L. (1968). Pediatrics, $42,912$.

Nadler, H. L., Chacko, C. M., and Rachmeler, M. (1970). Proceedings of the National Academy of Science, 67, 976.

$\mathrm{Ng}$, W. G., Bergren, W. R., and Donnell, G. N. (1964). Clinica Chimica Acta, 10, 337 .

Russell, J. D., and DeMars, R. (1967). Biochemical Genetics, 1, 11

Russell, J. D. (1968). Biochemical Genetics, 1, 301.

\section{MEDICAL MEMORANDA}

\section{Gross Impairment of Hepatic Drug Metabolism in a Patient with Chronic Liver Disease}

\author{
K. K. ADJEPON-YAMOAH, J. NIMMO, \\ L. F. PRESCOTT
}

British Medical fournal, 1974, 4, 387-388

The biotransformation of drugs occurs mainly in the liver. Patients with liver disease may therefore be unable to metabolize drugs normally and effects may be exaggerated and prolonged with an increased risk of toxicity. Selden and Sasahara, 1967). The results of drug metabolism studies in patients with liver disease have been conflicting, however, and some workers have reported a normal or even an increased rate of drug metabolism (Nelson, 1964; Held and Oldershausen, 1971). We found such gross impairment of lignocaine and antipyrine (phenazone) metabolism in a young woman with active chronic hepatitis that chronic administration of many drugs in conventional doses would undoubtedly have led to rapid cumulation with severe and probably fatal toxicity.

\footnotetext{
University Department of Therapeutics, Royal Infirmary, Edinburgh EH3 9YW

K. K. ADJEPON-YAMOAH, M.R.C.P., Lecturer

L. F. PRESCOTT, M.D., F.R.C.P., Reader in Clinical Pharmacology and Consultant Physician

Gastrointestinal Unit, Western General Hospital, Edinburgh EH4 2LE

J. NIMMO, M.R.C.P., Senior Lecturer and Consultant Physician
}

\section{Case Report}

A 28-year-old housewife was first admitted to hospital in 1968 with painless jaundice which resolved spontaneously after nine months. She remained well until 1970 when there was a recurrence of jaundice associated with dark urine, pale stools, and pruritus. Despite treatment with prednisolone in doses of up to $60 \mathrm{mg}$ daily her condition did not improve, and in April 1973 she was readmitted to hospital because of anorexia, vomiting, upper abdominal pain, and increasing ankle oedema. One examination she was fully orientated and there was no evidence of hepatic precoma. She was deeply jaundiced, with multiple spider naevi, moderate hepatosplenomegaly, and ascites.

Laboratory investigations were as follows: prothrombin ratio 3.6:1, serum bilirubin $11.3 \mathrm{mg} / 100 \mathrm{ml}$, alkaline phosphatase $170 \mathrm{~K}$. A. units, aspartate and alanine aminotransferases $129 \mathrm{IU} / 1$. and $29 \mathrm{IU} / 1$. respectively, total plasma proteins $8.7 \mathrm{~g} / 100 \mathrm{ml}$ (albumin $26.2 \%$ and gammaglobulin $57.4 \%$ ), and plasma urea $21 \mathrm{mg} / 100 \mathrm{ml}$. Tests for antinuclear factor were positive, but antibodies to mitochondrial, smooth muscle, and hepatitis $\mathbf{B}$ antigen were not detected. There was no radiographical evidence of oesophageal varices. The patient was a Jehovah's Witness and a liver biopsy was considered an unjustifiable risk without permission to give a blood transfusion. A diagnosis of active chronic hepatitis was made. Drug therapy before admission had consisted of oral and intramuscular phytomenadione, prednisolone, Slow-K, and frusemide: spironolactone and folic acid were added after admission.

\section{DRUG METABOLISM STUDIES}

Twenty days after admission the patient ingested $400 \mathrm{mg}$ lignocaine hydrochloride with $40 \mathrm{ml}$ of water after an overnight fast. Venous blood was sampled at intervals for eight hours and urine was collected for three days. Five days later $18 \mathrm{mg} / \mathrm{kg}$ of antipyrine was given by mouth and the plasma half life was measured as described by O'Malley et al. (1971).

Control studies of lignocaine metabolism were carried out in seven healthy ambulant adult male volunteers aged 19-37 years. Plasma and urine samples were stored at $-20^{\circ} \mathrm{C}$. Lignocaine, its metabolites ethylglycylxylidide (EGX), glycylxylidide (GX), and 4-hydroxyxylidine, and antipyrine were estimated by gas-liquid chromatographic methods (Adjepon-Yamoah, 1973; Prescott et al., 1973). 